\title{
Rehabilitation of Narcotics Addicts as the Rights to Health
}

\author{
${ }^{1}$ Sarwirini \\ Faculty of Law, Airlangga University \\ Surabaya, Indonesia \\ Sarwirini.rini@gmail.com
}

\begin{abstract}
Illegal Narcotic addiction can be qualified as commiting crime. The punishment for illegal drug offender and place them to prison is far from success to reduce the rate of illegal narcotics consumtion. The offenders tend to come back to their addiction and turn them to commit crime related with illegal drug trafficking. The objective by punished the illegal drug offenders could not meet its goal and should be amendment. One of alteration strategy to release the offender from addiction is rehabilitation program. This program will treat the offenders recover from the addiction and reduce the negative impact of punishment. Furthermore rehabilitation would cohere with the rights for health.
\end{abstract}

Keywords- Drug Addiction; Rights of Health.

\section{INTRODUCTION}

Narcotic crimes continue to show an alarming development both in practice and by the perpetrators. The current development of narcotics crimes involves not only the jurisdiction of the country where the crime takes place, but it also involves jurisdictions of various countries. The development of narcotics crime evolves not only into crimes of transnational, but perpetrators of such crimes implicate networks of international crime and criminal organization as the impact of these transnational criminal acts. The main concern of the above issue was demonstrated by Kofi Annan, the UN General Secretary, who at the time, suggested the following:1(GoldSmith, Andrew.2006."Crime Across Border." In Crime and Justice: A Guide to Criminology edited by Andrew Goldsmith)

\author{
${ }^{2}$ Riza Alifianto Kurniawan \\ Faculty of Law, Airlangga University \\ Surabaya, Indonesia \\ alifriza@fh.unair.ac.id
}

Illicit drugs destroy innumerable individual lives and undermine our societies. Confronting the illicit trade in drugs and its effects remains a major challenge for the international community, although the consumption of drugs has been a fact of life for centuries. Addiction has mushroomed over the last five decades. It now demands a determined and international response.

The above points show that narcotics crime has become the world's concern and requires every country to have an active role in the eradication and prevention of the said crime. The statement from Kofi Annan about the threats from narcotics crime is nothing new, but there is an arising problem in which public considers the use of illegal narcotics as unlawful, and so with producing and distributing it illegally.

According to Neil Boist, transnational crime is a phenomenon type of crime that crosses international border(s), breaks the law of multiple countries and/or has harmful effects on other countries. On the other hand, GOW Miller suggests that the term transnational crime derives from the study of criminology, thus it is a not a legal term. The term was created by the United Nations Office on Drugs and Crime in order to identify the phenomenon of this type of crime that crosses international borders, breaks the law of multiple countries or has an adverse impact on other countries. Whereas characteristics of Transnational organized crime according to Petrus Reinhard Golose (2013), are, among others:

1. Organized in hierarchy and continuous

2. Gain profitability through criminal acts

3. Use force and threats 
4. Implicate corruption in order to gain immunity (from the law)

5. Supply public consumption/needs

6. Monopolize certain markets

7. Closed memberships

8. Non-ideological

9. Have specialized work division

10. Have rules to keep secrecy

\section{Widely organized}

The objective of law amendment on narcotics, from Law No. 22 Year 1997 to Law No. 35 Year 2009 is to improve regulatory of law on narcotics in Indonesia. One of the driving forces to change the law is the high number of casualties of drug addicts among adolescents. The high rate of drug addiction among adolescents becomes an issue in preventing the misuse of narcotics in Indonesia. Compared to the previous law, law no. 35 Year 2009 on Narcotics is much more developed in terms of concepts of prevention and treatment for narcotics abusers. The new Law gives options for the judge to either penalize criminal sentence or decide to award rehabilitation to drug addicts. The aforesaid provision is an option and is depended on the judge's right to sentence.

Indonesian government policy related to narcotics which are based on the Law No. 35 Year 2009 on Narcotics, has specifically defined the criteria of user, middleman, dealer and manufacturer of illegal narcotics into different categories, however, in imposing sanctions onto users, middleman, dealer and manufacturer all together are categorized as offenders who may be sentenced to imprisonment, confinement or fines.

Policy applied onto drug users is actually an act of criminalization, so Correctional Institution (hereinafter referred as CI) plays a central position that is crucial in implementing policies dealing with illicit trafficking and abuse of narcotic. Accordingly, apart from being used as a place for the middlemen, dealers, manufacturers, and users to serve their sentences, $\mathrm{CI}$ is also often utilized as a rehabilitation center for users to lessen the adverse effects caused by the use of narcotics and to protect the community2. In such case, drug addicts are victims of narcotics abuse.

The position of such victims (in the perspective of criminal law) is considered as a party who suffers physically, psychologically, and financial loss due to the crime they committed. The victim as the aggrieved party in drug abuse should receive help for treatment, so that he/she can recover and back to his/her normal condition. However, in the case of drug abuse, the drug addict is an abuser/perpetrator of narcotics abuse. As a perpetrator, the addict may receive consequences of criminal prosecution.

The addict should not be convicted as perpetrator because he/she is a victim of abuse. Instead, the addict should receive sanctions in the form of rehabilitation. The basic regulatory related to the above points is regulated within Law No. 35 Year 2009. A judge can apply sentences of rehabilitation onto narcotics addicts. In addition, from the perspective of health law, drug addicts are patients who need to be cured and break their addiction on drugs. Addicts have the right to health, to be cured and to receive treatment so that they can recover and break away from such addiction.

The right to health for drug addicts absolutely needs to be guaranteed and protected. A form of protection for narcotics addicts to break away from addiction is by sending the said addicts for rehabilitation treatment. Rehabilitating drug addicts to break away from his/her addiction and recovering one's condition and become free from drug addiction are something that need to be applied and used a policy so that the addicts shall receive their rights and quickly recover.

Within the blueprint for Implementation Renewal of Correctional System in Indonesia, it is stated that within a specific context of mentoring for inmates who commit certain crimes, such inmates should receive more attention in the implementation reform of correctional system. Such mentoring models must be specially designed for specific crimes that come under international focus. Those special treatments include: 
First, treatment for inmates and mentees involved in narcotics cases as users of narcotics and psychotropic substances. For all intents and purposes, treatments shall be in the form of rehabilitation through creating a cooperation program with the Ministry of Health and Social Affairs. Meanwhile, the government should still create a specific program of a thorough coaching the mindset and behavioral change of inmates involved in the trafficking and production, and the said inmates shall be placed in special cells. In terms of mentoring system for dealers and producers, apart from receiving physical rehabilitation, the said inmates shall be directed towards having the ability to work in other fields, for example: businesses that are more profitable and harmless to other people, be indoctrinated on the danger of narcotics substances as well as its impacts on users.

Second, in cases where inmates are guilty of committing terrorism, it is important to set up specific mentoring system, e.g. Deradicalization Program with an accurate method on issues of jihad and an understanding of a more inclusive Islam. Islamic groups who have the expertise in the said program shall be included (in the program) and accompanied by strengthening officers' capability in charge for this special mentoring. In terms of prevention, the government needs to prepare mentoring systems for inmates who are accused of conducting terrorism and whose actions were based on fanatical/radical religions and other beliefs.

Third, in cases of corruption, the government needs to create mentoring and coaching systems for the said inmates. Most corruptors have higher education and intellectual capability; hence it is important that those inmates have the right access to daily activities. During the coaching/mentoring process, we need to study the importance of creating specific CI for corruptor inmates.

Fourth, felonies of human rights violations. Considering that felonies of human rights violation are people who have strong accesses to politics and economy, the government will need to formulate an appropriate system of guidance and treatment applied to felonies of human right violations.
Fifth, treatment to mentoring prisoners of political crimes and blasphemy needs to be set up specifically. Cases of political crime and blasphemy in Indonesia have a decade-old history, and so with its treatment and mentoring systems within Indonesian prisons. In a country that upholds democratic values, officers need to have sufficient knowledge in treating the said inmates, on how to fulfill the needs of inmates while respecting the differences in perspectives.

From the first point of the pertaining Blueprint, it is known that the plan to formulate the mentoring policy for narcotics addicts is urgent. Therefore, the danger of drug abuse particularly among young generation jeopardizes the survival of a nation. For the above reason, rehabilitation program is planned to be coordinated with various parties, both interministries and inter-communities. Synergy of rehabilitation program formulation policy for drug addict would require the support from experts, especially interdisciplinary experts. To that end, in designing rehabilitation policy for drug addicts as an effort to fulfill their right to health, we need to study and examine other countries' experiences and successes in rehabilitating drug addicts.

\section{NARCOTICS ABUSERS IN LAW NO.35 YEAR 2009}

The abuse of narcotics has been a central issue. The high rate of narcotics abuse in Indonesia shows that this crime must be eradicated as well as the crime of corruption.

Several measures have been taken in dealing with the illicit trafficking, one of which by the regulatory amendment i.e. the repeal of Law No. 22 of 1997 and replaced it with Law No. 35 of 2009.

The Amendment of Narcotics Law has brought about improvements to prevention and law enforcement against illicit trafficking. Improvements in the new law correspond with the eradication of perpetrators among children, adolescents, and young generations in general. The narcotics perpetrators are actually also victims of illicit trafficking, by the reason that 
narcotics crime is classified as crime without victim in the perspective of criminology.

According to Law no. 35 Year 2009, narcotics perpetrators are both persons (naturlijk persoon) and corporation, both of legal entity as well as non-legal entity (recht persoon). By naturlijk persoon, the perpetrators include children and adult persons. In addition, Law No. 35 Year 2009 also regulates narcotics addicts. Definition of narcotics addicts according to article 1 point 13 is people using or abusing Narcotics and in a state of dependence on Narcotics, both physically and psychologically. Narcotics addicts can be children and adult persons.

Narcotics addicts are actually narcotics abusers because by the definition in narcotics law, narcotics addicts are also the abusers of narcotics and its precursors without rights. Drug addicts who do not report themselves may receive criminal penalties. According to law on narcotics, one consideration that might rule out criminal sentence against drug addicted defendants is when the said addicts self-report or were reported by their family.

There is strong possibility that underage children are among those drug addicts. For children who become narcotics addicts or drug abusers, narcotics law is used in enforcing criminal law.3 The legal criminal law applies the law of juvenile justice system. The law of juvenile justice system is the law that protects children who are suspected of committing a crime or breaking the law.

From the perspective of Law No. 35 Year 2009 on narcotics, narcotics addicts are offenders as well as victims of narcotics abuse. Qualification of drug addicts as drug abuse offender is based on article 127 Law No. 35 Year 2009, which gives criminal sanctions to drug addicts. Article 127 of the said law is the source of criminal law which prohibits any person to become a drug addict. In the said law, criminal offender is an adult offender. If the drug addict is a child, then the law of juvenile justice system shall be applied

A survey study found that several inmates continued using drugs inside the CI and they became even more addicted while serving their sentences. As much as $40 \%$ of the surveyed inmates said that they used drugs while serving their sentences (Singleton et.al., 1997). Furthermore, a number of data also shows that mortality rate of drug-addicted inmates among other inmates in DKI Jakarta correctional Institutions/Jails is the highest, i.e. $85 \%-90 \%$ (Ditbinsustik, 2007). Further examination on this number reveals that the caused of deaths is HIV/AIDS; it is also suspected that the spreads of the disease is closely related to the use of narcotics with syringes in $\mathrm{CI} / \mathrm{jail}$.

According to a report from Indonesian National Police (POLRI), in 2013 there were four types of transnational crimes or criminal acts in Indonesia that crossed international borders. They are: terrorism, illicit drug trafficking, human trafficking, illegal immigration and smuggling of firearms. Indonesian Chief of Police stated that crimes without borders and regions, even across countries are increasingly rampant and widespread. The above development is in conjunction with the increasing mobility of residents between countries that will have an impact on the increased mobility and transnational crime mode (Tribune.com, July 17, 2013).

In this globalization era, studies on the abuse and illicit trafficking of narcotics, psychotropic substances and other harmful materials are studies within the issues of national and international scope. In reality, drug crime has become a transnational crime committed by organized crimes.4 Drug-related crime in Indonesia is quite alarming. Previously Indonesia was set as a country for illicit trafficking of narcotics, however, Indonesia nowadays is not just consumer for the abuse but has also become one of narcotics and other illicit drugs country producer. An increasing tendency of drug-related crimes can be seen by the increasing number of reported cases and the number of suspects involved, both as drug users as well as drug dealers. The above statistical data is taken from National Narcotics Agency $(\mathrm{BNN})$ 
Abuse and illicit trafficking of narcotics, psychotropic substances and other harmful materials is a study within the issues of national and international scope. In reality, drug crime has become a transnational crime committed by organized crimes. Drug-related crime in Indonesia is quite alarming. Previously Indonesia was set as a country for illicit trafficking of narcotics, however, Indonesia nowadays is not just a consumer for the abuse but has also become one of narcotics and other illicit drugs country producer.

An increasing tendency of drug-related crimes can be seen by the increasing number of reported cases and the number of suspects involved, both as drug users as well as drug dealers. Based on the statistical data taken from National Narcotics Agency (BNN), distribution of methamphetamine has continued to increase since 2006. This is reflected on the increase number of cases and suspects of methamphetamine and the number reached its peak in 2009 (10,742 cases and 10,183 suspects). Nowadays, law enforcement policy against illegal illicit trafficking, and rehabilitation of drug addicts is seemingly addressed more by the BNN. To achieve the success of such effort, BNN should certainly carefully consider the various aspects within community life which could have an effect on the implementation of law enforcement against illegal drug-related trafficking.

\section{THE REHABILITATION FOR NARCOTIC ADDICT: THE BEST INTEREST PRINCIPLE}

According to Soejono Soekanto (2004), there are 5 (five) factors closely related and essentials to law enforcement, and those factors become the benchmark on the effectiveness of law enforcement itself. Those five factors are:

(a) Legal;

(b) Law enforcement apparatus, i.e. Various Parties that establish and enforce the law; (c) Means or facilities to support the rule of law;

(d) Community, i.e. the environment/place where the laws are applied; and

(e) Culture, resulted from work, creativity, and senses based on human initiative in social life.

According to article 103, Law No. 35 Year 2009 on implementing law enforcement onto drug addicts, it is possible not to give criminal penalties to the said addicts. One of the amendments within the aforesaid Law is the provision on rehabilitation. Rehabilitation within Law No. 35 Year 2009 is stipulated more specifically for drug addicts. In article 103 on Narcotics Law, the Judge who examines drug addict case may instead decide to award rehabilitation stipulation. The above provision is further clarified in explanation of Article 103 on Narcotics Law, that such judge's decision for a defendant to undergo rehabilitation is (only) for drug addict not guilty of criminal offense(s) and that it is mandatory for him/her to undergo treatment and care. The cost for treatment and care of drug addict is borne by the state. The subject of the law on drug addicts in Narcotics Law also includes child drug addicts.

The non-penalty policy for not awarding criminal penalty to narcotics/drug addict offender is the right policy. Drug addicts, in particular child drug addicts, need protection and care more than criminal sentence. The provision of article 103 in Narcotics Law is a form of non-penalty policy for drug addicts, both onto adult and child addicts

The concept of awarding rehabilitation to drug addicts is also coherent to fulfill the right to health. Everyone who experiences or suffers an illness/disease has the right to recover or the right to quality heathcare treatment6. In the case 
of drug addict, the condition of addiction toward a certain drug is considered as health disorder/problems. Thus, it is appropriate that drug addicts receive treatment to be cured or be free from their addiction.

The legal basis for awarding rehabilitation is the right to health, i.e. article 4, Law No. 36 Year 2009 on Health. Article 4 states that everyone has the right to health. According to above mentioned law, health is defined as a one's condition of being healthy thus allows one to live productively, both socially and economically. The above definition of health aims to make everyone productive, both economically and socially.

An addict who serves his/her sentence will have difficulty to recover from his/her addiction and this creates risks for crime repetition if the person cannot be cured/recovered through rehabilitation. Based on a survey conducted by BNN and University of Indonesia in 2008, the number of drug addicts in Indonesia has reached 3.6 millions people or about $1.99 \%$ of Indonesian total population. In 2010, the number was predicted to have increased to $2.21 \%$. If the issues were not dealt seriously, it was estimated that the prevalence of drug abuse in 2015 could reach up to $2.8 \%$ or about 5.1 millions people involved in drug abuse. Other data shows that drug addicts who went into new treatment and rehabilitation is maximum $0.5 \%$ of the total drug addicts, and the rests stay within communities. Ironically, public awareness regarding issues of drug abuse is still low. Access to information received by the public on issues of drug abuse is also very limited; for this reason, the media is expected to report accurate and correct news/information related to P4GN comprehensively, based on facts and up to date.

The commitment shown by the government to combating issues of drug addicts, are, among others: issuing Government Regulation No. 25 Year 2011 that regulates compulsory reporting for drug users. The said Government Regulation derives from article 55 paragraph (3) Narcotics Law No.35 Year 2009 regarding the right of drug addict to undergo Medical and Social Rehabilitation.

According to a study conducted on several Correctional Institutions (Class II A Jember CI, Class II Malang CI, Madiun Narcotics CI, Class I Surabaya CI and Class IIA Pamekasan CI), in so far only Pamekasan Class IIA and Madiun CI provide special treatment to inmates who use drugs. Currently, Class IIA Pamekasan CI is being prepared to become a Specialized Narcotics Correctional Institution. Pamekasan $\mathrm{CI}$ is currently preparing building facilities for Specialized Narcotics Correctional, whilst the construction of buildings for specialized narcotics correctional in Madiun is yet to begin. There is no specific separation between users, dealers and producers among the said inmates who are currently placed in both general and specialized narcotics $\mathrm{CI}$; all of them are currently placed in cells based on the length of their sentence. At the same, other Public CI such as Lowok Waru CI Malang, Jember CI and Porong Sidoarjo CI do not distinguish their treatments towards for drug-addicted inmates and inmates of other type of offense. The said CIs do not differentiate treatments toward their inmates because, according to the officials in charge, those inmates were temporarily assigned to their CI and shall be later sent to specialized narcotics correctional institutions. Despite the fact that in public CIs the said inmates, especially the drug addicts, need different type of space and treatment from other offenders, but only Pamekasan CI differentiates its treatment towards general offenders and special offender of narcotics. Special drugaddicted inmates are given medical treatment when they experience seizures or addiction attack, however, unlike regular inmates; they are not awarded with assimilation program. From the five correctional institutionals in the study, more than $50 \%$ inmates in the CI were 
drug-related offenders and most of them are drug users.

(Table: Number of Inmates)

\begin{tabular}{|c|c|c|c|c|}
\hline $\begin{array}{c}\text { Name of } \\
\text { Correctional } \\
\text { Institution }\end{array}$ & $\begin{array}{l}\text { Name } \\
\text { of } \\
\text { Inmat } \\
\text { e }\end{array}$ & $\begin{array}{l}\text { Drug- } \\
\text { addicte } \\
\qquad \mathrm{d} \\
\text { inmates }\end{array}$ & $\begin{array}{c}\text { Total } \\
\text { Numbe } \\
\mathrm{r}\end{array}$ & $\begin{array}{c}\text { Descriptio } \\
n\end{array}$ \\
\hline Sidoarjo & 644 & 890 & 1534 & \\
\hline $\begin{array}{l}\text { Pamekasa } \\
\mathrm{n}\end{array}$ & 238 & 514 & 752 & $\begin{array}{l}\text { Users: } \\
375 \\
\text { Dealers: } \\
136 \\
\text { Producer } \\
: \\
3\end{array}$ \\
\hline Madiun & 552 & 579 & 1131 & \\
\hline
\end{tabular}

Based on the result of the study, it was revealed that $53.91 \%$ of the inmates were drug users and $6.76 \%$ were drug dealers. The rests are combination of drug users and dealers. The drug-abuse inmates that are included to these criteria are also those who own/store, couriers or middlemen, or those who grew marijuana. There is no specific educational background of these drug-related inmates. Approximately $53.8 \%$ drug-addicted inmates received high school education or higher and about $26.3 \%$ received junior high school-education. About $5.8 \%$ of them are with no school education or did not complete their primary school education. Based on their marital status, most them are unmarried (36.2\%).

Based on their occupation, prior to their prison sentencing, majority of the said inmates were employees/workers (72.5\%). This is understandable because drugs are not cheap, therefore only workers/people with jobs can afford them. Based on their earnings, nearly half or $45.1 \%$ of these inmates had income of less than IDR 500,000 per month. About $41.3 \%$ of them had income between IDR 500,000 to IDR 1.5 million. The rest of them earned over IDR 1.5 millions and worked with their family.

The majority of these inmates came from communities that have a common sense of togetherness. It is shown on the high number of inmates whose neighborhood still conduct reciprocity or mutual aid activities (83.5\%), visiting people activities (83.3\%), and worshiping together $(79.8 \%)$. In addition, about $71 \%$ of them came from neighborhoods that provided places/space where young people gather and play together. About $50 \%$ of these inmates had their first experiment with drugs because (1) out of curiosity (2) wanted to forget their problems and (3) it was given for free by their friends/family. Only $0.6 \%$ of these inmates said they were forced to use drugs by their friends. Issue about drug abuse that it has penetrated to school age children is real. Almost half $(48.7 \%)$ of drug-addicted inmates had been using drugs before the age of 19. In fact, $10.7 \%$ of them had used drugs since before they were 14 years old. 7

It is interesting to study or analyze the effectiveness of drug dealers in infiltrating drugs to early age children. Based on information about from which/whom the drug was first obtained, it was revealed that the drugs were distributed via friends. A total of $82.6 \%$ of drug-addicted inmates said that they were first given for free by their friends. Only about $12.4 \%$ of drug-addicted inmates said that they had it first time by purchasing it. Ironically, there were also members of their families who wanted to destroy the future of their own. A reality among the communities proves one indication that there is a possibility of scenario to use drugs to destroy a nation. 
Indonesia is currently dealing with the phenomenon of a large number of drug abuser in Indonesia, as well as the spread of HIV AIDS that as one of the worst negative impact of sharing same needles and syringes (IDU = Injection Drug Users). The Ministry of Health and the National Control Commission of AIDS noted that as many as 90,300 people living with HIV were infected through sharing the same needles and syringes. To cope with the vast spread of HIV AIDS via sharing same needles and syringes, the government issued Regulation of Ministry of Public Welfare No. 02 Year 2007 (National Policy on countermeasure of HIV and AIDS reducing the adverse effects of narcotics injection). These policies include the provision of sterile needles, methadone substitution therapy, and HIV treatment and care for IDU users. Nowadays, a wide range of public health services and non-governmental organizations have been implementing the Policy from Ministry of Public Welfare by reaching IDU users and asking them to exchange used needles/syringes with new needles/syringes.

The growing cases of drug abuse annually make it risky for correctional institutions to the spread of HIV. There was no denying that the exceeding capacity conditions within Correctional Institutions and the limited capacity of health facilities play the roles in the spread of HIV in Correctional Institutions.8 Moreover, it is suggested that the number of human resource that is not comparable to the number of CI's occupants is also one of the determinant factors causing the current rampant trafficking and drug abuse within CI. The number of inmates with HIV positive in Pamekasan CI was 10 (ten) in 2008 -2011 and was 3 (three) in 2011.

Correctional Institutions assigned to mentor the said inmates also function as therapy and rehabilitation institutions for drug users; hence with help of these programs, the said inmates are expected to return to their active roles within society, free from drug addiction. Treatments for drug abusers require a structured and well-planned method so that it will achieve its target. Based on a study conducted in Surabaya, Lowok Waru Malang, Jember, Madiun and Pamekasan CIs, only Pamekasan CI conducted training specifically against drugcrime offenders with a system called One Stop Center (OSC) and Therapy Community (TC). The One Stop Center (OSC) provides medical treatment and rehabilitation services under one roof. The goal of OSC is to help the recovery process of the mentored inmates free from their drug addiction. With the activities provided by OSC, it is expected that inmates shall get the right mentoring based on their needs while serving their sentences. As such, when they return to community, they can readily integrate and have an active role (Astutik dan Toetik Rahayuningsih, 2011). The UN believes that the success of sentencing process starts from treating inmates as human being. As stated in articles 58 and 60 conventions

58. The purpose and justification of a sentence of imprisonment or a similar measure deprivative of liberty is ultimately to protect society against crime. This end can only be achieved if the period of imprisonment is used to ensure, so far as possible, that upon his return to society the offender is not only willing but able to lead a law-abiding and self-supporting life.

60. (1) The regime of the institution should seek to minimize any differences between prison life and life at liberty which tend to lessen the responsibility of the prisoners or the respect due to their dignity as human beings

Indonesia, who embraces philosophy of reintegration and socialization within its criminal normative system, regulates application of the rights of inmates as one important factor within the process criminal prosecution. It is stated in articles 2, 5, and 14 Law No. 12 Year 1995. 


\section{Article 2}

The correctional system is organized in a way to form correctional mentored inmates, so they shall function as normal human being, aware of their mistake, improve themselves, and not to repeat criminal offenses; hopefully, they will be welcomed by the community, actively participate in development, and live a normal life as good and responsible citizens.

\section{Article 5}

The correctional system is executed based on the below principles:
a. patronage
b. equality of treatment and service;
c. education;
d. mentoring
e. respect for human dignity and values;
f. loss of independence shall be the only adversity; and
g. guarantee of the right to stay in touch with family and certain people.

\section{Article 14}

Inmate has the right to:

a. worship according to his/her religion or belief;

b. receive care treatment, both spiritual and physical ;

c. receive education and teaching;

d. receive good health services and decent food;

e. file a complaint;

f. receive reading materials and access to other unprohibited broadcast media;

g. receive payment or premium for the work performed; h. receive family visits, legal counsel, or other particular people;

i. treceive a sentence reduction (remission);

j. treceive the opportunity to assimilate including home leave

$\mathrm{k}$. receive parole;

1. receive time off ahead of completing the sentence; and

m. receive other rights according to the current law and regulation.

\section{REHABILITATION PROGRAM AS VICTIM RECOVERY POLICY}

Indonesian Correctional Institutional reform policy seeks to change the condition of inmates through mentoring process and treating them humanely by protecting the rights of inmates. A correctional concept using a reintegration scheme of inmates and community makes the fulfillment of inmates' basic rights of prisoners as one indicator of successful correctional service implementation. With humane treatment, it is hoped that the process of education and training in CI will be more effective (Sarwirini, Didik Endro P., and Maradona (2013)

Mentoring drug addicts in prisons is a challenge in itself. It requires more specific training programs and focus on the addicted behavior. In a study of special narcotics CI, drug addicts must be willing to go through several steps in recovery program, and they are:

\section{a. Medical Rehabilitation}

In this step, inmates receive a thorough medical examination, both physical and mental health. The examination is conducted by physicians and nurses. During this process, we will see the extent of narcotics influences on inmates' mental and physical health. This process helps provide early treatment for the addicts who suffer infectious diseases such as 
HIV, Hepatitis and other types of infectious diseases. There are several program executed in this step, and those are9:

1. Methadone Substitution Programs This Program is one form of participation within narcotics correctional institutions in implementing government policy i.e. Harm Reduction in correctional institutions. Methadone program is a therapy program that helps heavy users of heroin, introduces them to new habit, and improves the life quality of its users without fears of withdrawal symptoms. The benefits of methadone program are:

- With the right dose, it will help addicts stop using heroin.

- It creates a stable mental emotion so that the addicts can live a normal life.

- It will encourage the addicts to live a healthier life.

- It will lower the risk of HIV/AIDS, Hepatitis B and C transmission due to the use of unsterilized shared needles.

- $\quad$ It can lower crime rate.

- $\quad$ It makes people feel much better.

\section{Complementary}

Therapy

Complementary therapy is an

Adjunctive, complementary or supporting therapy which relies on one's potentials and the nature. In this therapy, one will be taught about few medicinal science derived from traditional and science medicine. Types of complementary therapy are:

- Breathing exercise

- Meditation

- Acupuncture

- $\quad$ Prana (breathing for life) food

Maintaining health through healthy

The benefits of complementary therapies are:

- Prevent sickness and maintain immune system

- Maintain stamina and immune system

- Overcome mild physical complaints

- $\quad$ Reduce and avoid stress

b. Non-Medical Rehabilitation

In this step, inmates undergo one of therapy rehabilitation program which aims to change the addictive behavior that does not comply with societal norms. Through group support therapy, the addicts receive guidance and learning on how to be assertive leaving and refusing to take drugs.

Several non-medical programs are offered, and those are:

1. Therapeutic Community (TC) TC is a recovery program that helps change the addictive behavior of drug abusers towards "Healthy Life Style" (without drugs). Some types of activities could be in group therapy or commonly know as "family". Those types of activities are conducted as follow:
a. Morning Meeting
b. Encounter group
c. Mix Confrontation
d. Static Group
e. PAGE group
f. Seminar
g. Morning Briefing 


\section{Criminon}

Criminon means No Crime; its objective is to reform inmates so they will not back to committing criminal acts/offenses. The basic philosophy of criminon states that a person basically commits a crime due to lack of confidence. The absence of confidence results in that person unable to face challenges in life and unable to adjust to the prevailing value system within the society so the person has the tendency to violate the law.

The objectives of Criminon training are:

a. To help improve and increase the ability of a person in dealing with guilt, low self-esteem, fear, emotions and so the person is able to control him/herself.

b. To assist the inmates dealing with barriers to learn.

c. To provide knowledge to achieve better happiness for oneself and others.

d. To provide basic knowledge to achieve stability and life happiness.

In enforcing the law against narcotic crimes, there are several particular obstacles related to drug addicts. Narcotics Law provides alternatives in handling addicted offenders i.e. for the law enforcement officials to either give reward rehabilitation or sentence of imprisonment. As in the case of criminal act or a crime, drug addicts could be the subjects to criminal punishment as the consequence of criminal offense. One obstacle in the provision of rehabilitation for addicts is there is no clear definition or standardization on qualification of addict. One standard definition in the Narcotics Laws states that narcotics addicts are victims of narcotics abuse. The authority to determine status of narcotics abuse victim is given to investigators, prosecutors, and judges who handle narcotics case. The most worrying issue is inaccurate qualification or abuse of authority in giving the status as an addict; the system shall not let narcotics abusers or narcotics dealers be classified as drug/narcotics addicts which could be detrimental to law enforcement Notwithstanding, qualifications that serve as a guideline and must be followed through in carrying out the execution on the addicts are as follow (Sarwirini, 2014):

a. Drug users are not criminals

b. Drug users must be cured/recovered so as not to fall into drug addicts or even become dealers or traffickers

c. Correctional Institution (CI) is not a place for healing. Precisely in CI, where the number of occupants always exceeds its capacity, seemingly, and most of them are inmates involved in narcotics, and there were indications of drug trafficking in CI.

d. Itisimportant to seek healing/recovery efforts by involving concerned users/parties.

1. Rehabilitation as a relief effort as well as recovery for the victim and others related parties.

a. Rehabilitation as an implication of legal failures (sanctions) to criminal in preventing drug abuse.

b. Benefits of rehabilitation for narcotics users

c. Obstacles in rehabilitation implementation of drug users.

2. Restorative justice as the basis for rehabilitation of narcotics addicts

a. The philosophy of restorative justice

b. The principles of restorative justice 
c. The internalization efforts of restorative values on law enforcement officers and officials.

3. Rehabilitation Arrangements Reformulation of drug users (decriminalization) via:

a. Actualization of restorative justice values on law enforcement agencies in implementing rehabilitation to minimize the emerging potential obstacles.

b. The Reformulation of Narcotics Correctional Establishment Policy and special rehabilitations for drug addicts is under the authority of the President of the Republic of Indonesia, and the authority is assigned and coordinated to BNN, National Police, Ministry of Justice and Human Rights, Ministry of Health, as well as local and provincial governments.

The three components are implemented in synergy and integrated by involving coordination among government officials and law enforcement officers and experts on medical therapy, psychologies, and social workers in order to provide a basic and thorough treatment on drug addicts.

Moreover, the necessary changes in the mindset of law enforcement officers to not always apply the provisions of imprisonment sentences, which by way of implementation is unfair and harmful towards drug addicts, but to opt for rehabilitation. For that reason, drug addicts are not criminals but victims of drug abuse that need to be cured and recovered, both physically, psychologically/mentally and socially. Thus we need a well-planned system using a method of therapy that is appropriate and can be accounted for effectiveness.

\section{CONCLUSION}

1. Drug addicts and drug-abusers are the two parties that can be held responsible when they consume or abuse narcotics without the right to do so and against the law. The distinction between addicts and drug abusers in Law No. 35 Year 2009 provides the options to the judge to deliver the verdict in the form of punishment or treatment (rehabilitation).

2. Policy decision of granting rehabilitation to addicts is one policy that aims to prevent drug addicts become drug abusers in the future. Law No. 35 Year 2009 gives the judge the freedom to not penalize drug abusers who qualify as narcotics addicts. As one element within criminal justice systems, a judge has the obligation to consider drug addicts as victims of narcotics drug abusers whom should be helped to recover and not to be convicted.

Suggestions

1. In enforcing cases of narcotic crime, investigators and prosecutors should act more carefully in qualifying narcotics abusers as drug addicts. Toward drug addicts, investigators and the prosecutors shall provide opportunity for the said addicts to undergo rehabilitation.

2. Ruling on rehabilitation should be more accountable. This is to prevent abuse of rehabilitation ruling so it shall not be exploited by narcotics offenders, especially those of organized crimes. Basis to be considered by the judge in giving a rehabilitation verdict should be in accordance with the laws and regulations and shall prioritize drug addicts' right to health.

\section{REFERENCES}

[1] Kusno Adi, Criminal Policy and Illegal Drug Law Enforcement Conducted by Juvenile Offender, UMM Press Malang, 2009 (Adi, Kusno, Kebijakan

Kriminal dan Penanggulangan Tindak 
Pidana Narkotika Oleh Anak, UMM Press Malang, 2009)

[2] Riza Alifianto Kurniawan, Ultimum Remidium Principles for Juvenile Deliquency, Yuridika, 2008 (Kurniawan, Riza Alifianto, Asas Ultimum Remidium Dalam Pemidanaan Anak Nakal, Yuridika, 2008)

[3] M. Togar Sianipar, Narcotic Problems in Indonesia, Police Journal, 2003. (M. Sianipar, Togar, Permasalahan Narkoba di Indonesia, Jurnal Kepolisian, 2003)

[4] Barda Nawawi Arief, Group of Article Criminal Law Policy, Citra Aditya Bakti, 1996. (Arief, Barda Nawawi, Bunga Rampai Kebijakan Hukum Pidana, Citra Aditya Bakti, 1996)

[5] M. Musa, Restorative Justice as An Alternative Juvenile Court in Indonesia, Legalitas.org (M. Musa, Peradilan Restoratif Suatu Pemikiran Alternatif Sistem Peradilan Anak di Indonesia, Legalitas.org.)

[6] Taufik Makaro, Narcotic Crimes in Indonesia, Ghalia Indonesia, 2003 (Makaro, Moh Taufik, Tindak Pidana Narkotika, Ghalia Indonesia, 2003)

[7] Siswanto Sunarso, (Law Enforcement in Psychotropic Crime, Rajagrafindo Persada, 2004 (Sunarso, Siswanto, Penegakan Hukum Psikotropika, RajaGrafindo Persada, 2004)

[8] Paulus Hadisuprapto, Juvenile Deliquency, 2008 (Hadisuprapto, Paulus, Delikuensi Anak,)

[9] Newburn, Tim, Criminology, Willan Publishing, 2007

[10] Syaefurrahman Albanjary, Tackling Illicit narcotic Offences, Restu Agung, 2005 (Albanjary, Syaefurrahman, Hitam Putih Polisi Dalam Mengungkap Jaringan Narkoba, Restu Agung, 2005)

[11] Abdul Rasul, Chief of indonesian Police Role in Eradicating Narcotic Crimes in Indonesia, Journal of Police Study, JanMar, 2003 (Abdul Rasul, Agung, Kinerja
Kapolri Dalam Memberantas Tindak Pidana Narkoba di Indonesia,Jurnal Studi Kepolisian,Edisi Januari-Maret,2003)

[12] Barda Nawawi Arif, Law Enforcement Problems and Crime Prevention Policies, Citra Aditya Bandung, 2001 (Arif, Barda Nawawi, Masalah Penegakan Hukum dan Kebijakan Penanggulangan Kejahatan,Citra Aditya Bandung, 2001)

[13] Badan Narkotika Nasional, Kumpulan Hasil - Hasil Penelitian Penyalahgunaan dan Peredaran Gelap Narkoba Di Indonesia Tahun 2003 - 2005, Puslitbang dan Info Lakhar BNN, 2007

[14] Dolan, Kate, Effat Merghati Khoei, Cinzia Brentari, Alex Stevens, Prisons and Drugs: A Global Review of Incarceration, Drug Use and Drug Services, The Becley Foundation Drug Policy Programme, 2007 (http://www.idpc.info)

[15] Leukefeld Carl G. Frank M.Tims, Ph.D. Drug Abuse Treatment in Prison and Jails, NIDA Research Monograph 118, National Institute on Drug Abuse, Rockville, 1992

[16] http://www.heuni.fi/uploads/f0gyxe5.pdf, A Study of Healt Care Profision Existing Drug Services and Strategies Operating in Prison in Ten Countries from central and Eastern Europe, European Institute for Crime Control, Affiliated with the United Nations (HEUNI), Helsinski, 2005

[17] Kaligis,O.C, Narkoba dan Peradilannya di Indonesia,Alumni, Bandung,2002 Kusnoadi,Kebijakan Kriminal dalam Penanggulangan Tindak Pidana Narkotika oleh Anak,UMM Press, Malang, 2009

[18] Kusno Adi ., Diversi Sebagai Upaya AlternatifPenanggulangan Tindak Pidana Narkotika Oleh Anak, UMM Pers, Malang, 2009.

[19] Priyatno Dwidja, Sistem Pelaksanaan Pidana Penjara Di Indonesia Refika Aditama, Bandung, 2006.

[20] Siswantoro,Sunarso,Penegakan Hukum Psikotropika, Grafindo Persada, Jakarta,2004 
[21] Taufik Makarao,Muhamad, Tindak Pidana Narkoba,Ghalia Indonesia, Jakarta,2003

[22] Roger,Harley,Randy C Philips, Who Graduates From Drug Courts?

Correlates of Client

Success,American journal of

Criminal Justice, Vol.26,No.1,2001

\section{List of Legal Materials}

[23] Undang Undang No 5 Tahun 1997 Tentang Psikotropika. (Law No 5 Year 1997 is about Psychotropic)

[24] Undang-Undang No. 35 Tahun 2009 Tentang Narkotika (Law No 35 Year 2009 is about Narcotic)

[25] Undang-undang No.12 Tahun 1995 Tentang Pemasyarakatan (law No 12 Year 1995 is about Correctional Institution)

[26] Peraturan Pemerintah No.31 Tahun 1999 Tentang Pembinaan dan Pembimbingan Warga Binaan Pemasyarakatan (Government Regulation No 31 Year 1999 is about Founding Principle for Inmates)

[27] Peraturan Pemerintah No.25 Tahun 2009 tentang Wajib Lapor Bagi Pecandu Narkotika (Government Regulation No 25

Year 2009 is about Disclosure

Obligation For Narcotic Addicts), p.14. 